\section{B A Institute of \\ YK Business Administration \\ 六下 \\ Karachi \\ Leadership and Ideas for Tomorrow}

Business Review

Volume 7 Issue 2 July-December 2012

7-1-2012

\title{
Treading conventional divides: The case for an alternative paradigmatic influence
}

Muhammad Nouman

Institute of Management Sciences, Peshawar, Pakistan

Follow this and additional works at: https://ir.iba.edu.pk/businessreview

Part of the Social and Behavioral Sciences Commons

(c) (;)

This work is licensed under a Creative Commons Attribution 4.0 International License.

\section{Recommended Citation}

Nouman, M. (2012). Treading conventional divides: The case for an alternative paradigmatic influence. Business Review, 7(2), 72-83. Retrieved from https://doi.org/10.54784/1990-6587.1204

This article is brought to you by iRepository for open access under the Creative Commons Attribution 4.0 License and is available at https://ir.iba.edu.pk/businessreview/vol7/iss2/5. For more information, please contact irepository@iba.edu.pk. 


\title{
ARTICLE
}

\section{Treading Conventional Divides: The Case for an Alternative Paradigmatic Influence}

\author{
Muhammad Nouman \\ Institute of Management Sciences, Peshawar, Pakistan
}

\begin{abstract}
Addressing ontological and epistemological issues remains a central concern in social sciences research. However, the two traditional paradigms that help us understand the nature of reality and knowledge offer very contrasting views of the world. This has resulted in 'paradigm wars' between the positivist and phenomenological schools of thought. Consequently Pakistani researchers' perspectives have also been influenced since they tend to view their research through the 'quantitative' or 'qualitative' lens only. Using literature review this paper highlights the salient but contrasting characteristics of the two paradigms in order to acknowledge differences between them. Then it points out the often ignored similarities between positivism and phenomenology, in order to highlight the futile nature of conventional paradigm divides. Emanating from these continuing debates, critical realism is presented as an alternative paradigmatic influence for researchers in Pakistan. An interpretation of this philosophical view in terms of differentiating the natural from the social world and some limitations of this perspective are presented. The paper concludes by pointing out that critical realism does not espouse the search for absolute truth about the world, the stance taken by 'purists'. Rather it focuses on providing an understanding of the underlying causal mechanisms that can help us arrive at a picture of the world that is as close to reality as possible while acknowledging the limitations of our conceptual resources.
\end{abstract}

Key words: Critical realism, Paradigm, Ontology, Epistemology.

\section{Introduction}

For any individual involved in social sciences research, two questions are of fundamental concern, answers to which will shape his/her thought process and views of the world. The first is about the nature of reality or how do we know what reality is. The second is about the nature of knowledge or what is valid/acceptable knowledge for us. Seeking answers to these questions has given rise to ontological and epistemological debates amongst the scientific community and has formed the basis for dividing it into various groups each with its own sets of philosophies/beliefs about what the world is and 
how we can understand it better. Bringing in the ontological perspective, one major dimension to how we view the social world around us is by understanding the dichotomy that exists between 'objective perspectives' and 'subjective perspectives' (Burrell \& Morgan, 1979). 'Objectivisim' takes up the position that social objects exist in reality external to social actors while 'Subjectivism' is the view that social phenomena are ingrained in the perceptions and actions of these actors (Saunders et al., 2006).

Taking into account epistemological considerations, two dominant stances namely positivist (also known as empiricist, logical positivism, logical empiricism, postpositivism) and constructivist (also known as interpretivist, phenomenological, naturalist) emerge. Referring to positivism Atkinson and Hammersley (1994, pp. 251) argue that 'social research should adopt scientific method' that involves 'the rigorous testing of hypothesis by means of data that take the form of quantitative measurements'. On the other hand constructivism is the view that data or observations are a result of individuals' inputs and interpretations. Thus to account for these diverse and varying individual perspectives qualitative methods are more appropriate (Tashakkori and Teddlie (2003).

Deriving from these competing ontological and epistemological perspectives, the purpose of this paper is to present literature review to;

- Describe the nature of 'paradigm wars' (Howe, 1988) that have dominated academic debates amongst research communities

- Highlight the often ignored similarities amongst the two traditional and rival paradigms 'positivism' and 'phenomenology'

- Offer an interpretation of 'critical realism' as a paradigm by arguing for the need to have an alternative approach to research rather than continuing the needless positivism vs. phenomenology debate.

\section{The 'Paradigm Wars'}

The term 'paradigm' derives from the work of Kuhn (1970) whereby he refers to it as a set of beliefs, values, assumptions and techniques that are shared by members of a society including scientific community. This shared way of thinking as characterized by Johnson and Duberley (2000) enables us to assign unique meanings to objects encountered while dealing with the world. However, having an agreement on what the word 'paradigm' means has not been easy to find. Referring to Thomas Kuhn, Guba (1990, pp. 17) state that he 'himself used the term in no fewer than 21 different ways'

Offering a succinct and useful definition Guba and Lincoln (1994, pp. 107) describe paradigms as 'basic belief systems based on ontological, epistemological and methodological assumptions'. Paradigms point to developments in scientific practice based on the view people have about the world and the nature of knowledge in the world. They serve as frameworks comprising of theories, methods and ways of defining data (Collis \& Hussey, 2003) and lay foundations of how a researcher looks at and understands 
things around him. Highlighting the influence paradigms have on choice of research strategy Hussey and Hussey (1997) provide a useful classification adopted below:

\begin{tabular}{|l|c|c|}
\hline \multicolumn{1}{|c|}{$\begin{array}{c}\text { Philosophy of Social } \\
\text { Science }\end{array}$} & $\begin{array}{c}\text { Phenomenological } \\
\text { Perspective }\end{array}$ & Positivist Perspective \\
\hline $\begin{array}{l}\text { Ontology: Focus on the } \\
\text { nature of reality }\end{array}$ & $\begin{array}{c}\text { Reality is subjective and not } \\
\text { single. It is open to how } \\
\text { people see it }\end{array}$ & $\begin{array}{c}\text { Reality is objective and } \\
\text { single. It is independent } \\
\text { of researcher }\end{array}$ \\
\hline $\begin{array}{l}\text { Epistemology: Focus on } \\
\text { the nature of knowledge }\end{array}$ & $\begin{array}{c}\text { Researcher becomes part of } \\
\text { the phenomena being } \\
\text { investigated }\end{array}$ & $\begin{array}{c}\text { Researcher remains } \\
\text { independent of the } \\
\text { phenomena being studied }\end{array}$ \\
\hline Axiology: Focus on values & $\begin{array}{c}\text { Researcher is influenced by } \\
\text { values, induces biasness }\end{array}$ & $\begin{array}{c}\text { Researcher remains free } \\
\text { of values and biasness }\end{array}$ \\
\hline
\end{tabular}

\begin{tabular}{|c|c|c|}
\hline \multirow{2}{*}{$\begin{array}{c}\text { Corresponding Research } \\
\text { Strategy }\end{array}$} & Case Studies & Surveys \\
& Action Research & Experiments \\
& Grounded Theory & Cross-sectional studies \\
& Ethnography etc. & Longitudinal studies etc. \\
\hline
\end{tabular}

Table 1.1: Adopted from Hussey, J. and Hussey, R. (1997)

Table 1.1 not only identifies key differences between positivism and phenomenology but also points out the all important influence they have on a researcher's choice of ensuing research methodologies. Consequently, this begs the question which paradigm should a researcher derive from as ultimately this choice influences everything else he will do in a research study. The answer is not easy to find because of the contrasting views of the world each paradigm espouses.

Easterby-Smith et al. (2002) point out strengths and weaknesses of both philosophical perspectives. For example, in praising the positivism they suggest that it provides wide coverage of a situation; is quick and economical as well as potentially more useful for decision-makers due to more reliable findings. On the contrary lack of flexibility and deeper understanding of processes from people's point of view are some of the limitations. Additionally, since quantitative studies tend to focus more on what is going on or what has been going on in a particular situation, they can potentially be of less use to decision-makers who want to infer changes for the future or a future course of action. In praising phenomenology the paradigm's ability to capture change over time, provide the individual's perspective or understand meaning and contribute to theory are pointed out. However, time consuming data collection process, difficulties in organizing and analyzing data and highly interpretive nature of meaning a researcher associates to findings and results are sited as some of the limitations.

Elaborating on differing perspectives Tashakkori and Teddlie (2003) point out three broad categories of researchers in social and behavioural sciences; (a) those with postpositivist orientation, (b) those with constructivist orientation and (c) mixed methodologists who work with pragmatism and transformative-emancipatory paradigms. Morse (1991) uses the terms 'QUANS' and 'QUALS' to describe the two opposing groups of researchers. According to Denzin and Lincoln (1994) it was the time-period 1950 - 1970 termed as 'Golden Age' that exposed positivism. The traditional paradigm 
was considerably undermined as a dominant philosophy of science (Reichardt \& Rallis, 1994) because of its weakness in addressing some of the deeper issues of social sciences. Addressing these concerns resulted in emergence of postpositvism characterized as being influenced by values and theories the researcher adheres to and his/her understanding of reality, views also held by mixed methodologists Taskakkori and Teddlie (2003).

It has been more than a century since proponents of quantitative and qualitative research paradigms have argued in favour of their respective philosophy. This resulted in emergence of purists on both sides (Campbell \& Stanley, 1963; Lincoln \& Guba, 1985). For quantitative purists social phenomena should be studied the same way as scientists study physical phenomena (Ayer, 1959; Popper, 2002). There has been the widespread view that only quantitative data is valid and of high quality. Nagel (1986) suggests that one should be able to generalize inquiries conducted in social science without the restrictions of time and context. Describing role of quantitative researchers Johnson and Onwuegbuzie (2004) suggest that they should always attempt to eliminate bias and remain detached from the objects of study. Their purpose should be to empirically test stated hypotheses about our views of the world

On the other hand purists who strongly favour qualitative approaches have traditionally argued for the supremacy of constructivism, idealism, relativism, humanism, hermeneutics (Guba \& Lincoln, 2005; Schwandt, 2000). Some of the criticism they put forward is concerning 'context stripping' that quantitative research applies in order to remove certain variables that might influence results otherwise. This puts into question generalizability of the study (Guba \& Lincoln, 1989). Another argument relates to the assertion that the theory a quantitative researcher would like to test using a hypothesis is external to the setting/context it is being applied to. In order for theories to be valid they should be qualitatively 'grounded' in the particular setting/context rather than being imposed from the outside (Glaser \& Strauss, 1977; Strauss \& Corbin, 1998). Another criticism mounted on positivists is that facts accumulated from a supposed objectiveoriented mindset of the researcher are relevant within a particular theoretical framework that originally formed the basis of hypothesis. This in return undermines the very issue of objectivity that quantitative research professes. Thus philosophers like Popper (2002) reject the concept of 'theory verification' and rather favour 'theory falsification' because of growing concerns that although a theory can be used to derive facts by way of deduction it is not possible to arrive at an overarching theory using facts by means of induction.

\section{Commonalities and Philosophical Debates}

The realm of social sciences seems more worried than natural sciences about the choice of methodologies for research (Meehl, 1978). The long-prevailing disagreements between the two dominant research philosophies have continued for so long that they have put forth the notion of 'incompatibility' of the two (Howe, 1988). This perception has been based on the contention that both quantitative and qualitative research paradigms along with their ensuing research methods can not and should not be mixed together. However, there are many who challenged this assertion by reminding us that mixed methods were already being used in many areas of research (Patton, 2002). Also, critics of the 'purist' school of thought highlight the similarities that exist between the two research philosophies as well as engage in philosophical debates that try to counter the epistemology-method link. Howe (1988) went on to question the so-called wisdom behind 'paradigm wars'. 
Looking at similarities Sechrest and Sedani (1995, p. 78) assert that both the quantitative and qualitative methodologies 'describe their data', develop 'explanatory arguments from their data', and attempt to explain 'why the outcomes they observed happened as they did.' Essentially all research within social sciences domain studies human beings in the context of their environments (Biesta \& Burbules, 2003) that is regardless of having a quantitative or qualitative leaning. Interestingly, while highlighting differences between the two paradigms, there are some who inadvertently make a case for commonalities. For example, addressing the issue of lack of context in quantitative studies, that is considered by qualitative research proponents to be a major limiting factor Bednarz (1985) points out that multivariate statistics has rapidly developed thus allowing quantitative researchers to address context limitations more and more as well.

Making a case for getting beyond the traditional divides Johnson and Onwuegbuzie (2004) point out the 'increasingly interdisciplinary, complex and dynamic' nature of today's research. Howe $(1988 ; 1992)$ advocates the need to separate epistemological considerations for a study from issues of research methods selection so that a researcher can use qualitative methods in quantitative studies and vice versa. However, it needs to be borne in mind that the 'compatibility' of research procedures/techniques does not mean that the debate over differences in epistemologies are over. Rather, proponents of the 'compatibility thesis' bypass the traditional philosophical divide by essentially questioning the usefulness of such divisive debates. Further elaborating on the issue of why traditional paradigm divides might be of little use, authors like Onwuegbuzie and Teddlie (2003) point out that the 'logic of justification' should not be confused with choice of research methods (data collection and analysis) a researcher employs. Taking this further Newman et al. (2003) advocate that the choice of data analysis techniques instead of being influenced by epistemological considerations should stem from purpose of research or questions the researcher seeks to answer.

Onwuegbuzie (2000, pp. 2) stresses the need for epistemological and paradigmatic 'ecumenicalism'. He suggests that although positivists profess the concept of science to mean 'confirmation', 'falsification' and 'objectivity', they forget that many decisions of a quantitative study are taken by researchers (human beings). Some of these decisions include issues of what to study, what instruments and tests to use, what conclusions/interpretations to draw and what findings to consider as significant or useful. These 'human' decisions are subjective in nature since they involve personal judgments. And it is not just quantitative researchers who have been prone to debates. Qualitative research has not been immune either. For example, qualitative purists like Guba (1990) point at the fact that they use relativism to accommodate the perspective of every individual or group to demonstrate subjectivity and generate multiple realities. However, as Johnson and Onwuegbuzie (2004, pp. 16) suggest any such account should be termed 'subjective reality' or 'intersubjective reality' rather than being called reality alone.

\section{Critical Realism: An Alternative Paradigm}

The discussion so far leads to the conclusion that the debate over traditional and long-standing philosophical perspectives of the world has been carrying on for many years with seemingly no end in sight. Consequently this has led some researchers to draw valuable lessons and suggest alternative paradigms and views about how we can understand the world around us better. Realism as an epistemological stance asserts that what our senses show us as reality is the truth however objects exist around us regardless of whether we as humans can sense them or not (Saunders et al., 2006). 
By stressing the notions that reality exists independent of the human mind and that researchers need to adapt scientific approaches to studying data in order to create knowledge, realism demonstrates strong characteristics of positivism. However, Johnson and Duberley (2000) signal caution against this overly simplified comparison. Part of the confusion stems from that fact that 'realism' as a term did not have a clear, single and agreed upon meaning for quite some time. Haack (1987) highlighted this ambiguity surrounding the term by reminding us that realism has had quite a few variants. For instance when looking at realism in the context of science and scientific theories terms like 'Theoretical Realism,' 'Cumulative Realism,' 'Progressive Realism' and 'Optimistic Realism' have been mentioned. On the other hand when considering issues of reality, truth, and the nature of truth we come across terms like 'Minimal Realism', 'Ambitious Absolutism', 'Transcendentalism', 'Nidealism' and 'Scholastic Realism'.

Taking the discussion further Saunders et al. (2006) remind us of two forms of realism namely 'direct realism' and 'critical realism.' Direct realism which in essence can be considered similar to empirical realism is the notion that what the human senses experience as reality is the truth. In other words, direct realists argue that we sense reality and truth directly and as they exist. Thus, when defining role of a researcher, Hammersley (1992) suggests that one should strive to produce narratives that correspond with reality. However, making the case for revising our understanding of realism when conducting social sciences and management research Johnson and Duberley (2000) point out that we should not;

'...conflate an objectivist epistemological stance with a realist ontological element in such a manner that...ignore(s) the possibility of combining alternative epistemologies with a realist ontology. Here, in understanding the role of such alternatives, it is initially necessary to realize that agreements with the idea that all knowledge is the outcome of social construction does not necessarily lead to a subjectivist ontology and the consequent notion that transactions between people (i.e. subjects) and reality (i.e. objects) have no role to play in the development of knowledge.'

(Johnson \& Duberley, 2000, pp. 150)

Further, Johnson \& Duberley (2000) go on to suggest;

'It is from the position that knowledge entails both social construction and the transactions of human knowers with an independent reality where it is possible to discern a very different understanding of realism.'

(Johnson \& Duberley, 2000, pp. 150)

The above-mentioned description presents an alternative form of realism 'critical realism' (Bhaskar, 1997) that is different from the concepts of direct realism or 'empirical realism' posited by others. It is important to mention at this point that critical realism came into existence and developed into a movement later on due to the seminal work of Roy Bhaskar in 1975. As an alternative paradigm it has been further elaborated upon by Bhaskar in his ensuing works in 1978, 1989 and 1997. Collier (1994) however reminds us that the term 'critical realism' is not Bhaskar's creation. Rather it came into existence as a result of 'elision' of the two terms 'transcendental realism' that is influenced by Immanuel Kant and 'critical naturalism'. Transcendental realism refers to general ontology whereby 
an individual is aware of the limitations of his mind while critical naturalism refers to development of implications that transcendental realism has had on human sciences.

Critical realists assert that the natural and social worlds are fundamentally different from each other in the sense that the latter is socially constructed meaning it is dependent on human action. On the other hand, the natural world remains independent of the social world and actions of human beings. As the social world is constructed based upon the understandings of individuals there are bound to be aspects to it of which human beings have no, limited or mistaken knowledge. Consequently, critical realism stresses the need to distinguish between ontology and epistemology. And avoid the 'epistemic fallacy' whereby the distinction between nature of reality and our knowledge of reality is so blurred that we think of the two as the same. While underscoring this difference it is important to remember that we cannot start assuming that reliable knowledge about reality can be developed easily. However, it does imply that while 'epistemic relativism' - the view that knowledge is socially constructed, is acceptable, 'judgemental relativism' - the view that all depictions of the world are equally correct and without any particular preference for one over the other should be rejected (Bhaskar, 1998). Hence the focus should be on whether some of these depictions or representations of the world provide us greater knowledge and understanding of the world than others or not (Fairclough, 2005).

Elaborating further on Roy Bhaskar, Dobson (2002) asserts that on one side we have 'real objects' and on the other we have 'value-laden observation of reality' by human beings. The former is non-transitional and relatively enduring while the latter is transitional and changing. The post-modernist view that espouses a relativist view of science and knowledge and contains both epistemic and judgemental relativism is criticized by Bhaskar for failing to appreciate this difference. Narrating a key difference between objects in social sciences and those in natural sciences Johnson \& Duberley (2000) explain that while our understanding of objects change due to transitioning nature of human thought, 'intransitive causal mechanisms' that are found in reality external to the human mind will not change unless these causal mechanisms are dependent on the actions of human beings themselves. To explain things further Bhaskar (1989a) presents the concept of 'stratified ontology'. It means that on one side reality consists of causal mechanisms and events that are the actual truth. On the other side, some and not all of these actual events are conceptually conceived through our empirical experience and observations. It is for this reason that critical realists do not construe causation and reality to mean all that is within the empirical realm of human judgement. Rather, critical realists go a step further to point out that causation and reality can be identified by further exploring the underlying causal mechanisms that result in actual events. A key to understanding critical realism is an appreciation and recognition of abstract forms of these structures and mechanisms that, although not directly observable, control the events we experience in this world. Bhaskar (1989b) goes on to use the term 'retroduction' as an alternative to the traditional deduction (related to positivistic approaches) and induction (related to phenomenological perspectives). Retroduction means describing the underlying structure or mechanism that has resulted in an apparent phenomenon.

Apart from Bhaskar critical realism as a philosophical thought in social sciences has had significant contribution from Margaret Scotford Archer through her book Realist Social Theory: The Morphogenetic Approach published in 1995 and Andrew Sayer Realism and Social Sciences published in 2000. While explaining the concept of 'stratified ontology' mentioned earlier Fairclough (2005) explains that it draws a distinction among 
the 'real, the 'actual' and the 'empirical.' The 'real' includes structures with their related 'causal' mechanisms. The 'actual' includes events and processes. While the 'empirical' includes that part of the real and actual that is experienced by social actors. In the case of social sciences critical realism claims that there are mediating entities that is social practices that account for the relationship between the 'real' structures and the processes/events.

Taking influence from Bhaskar's ideas Johnson and Duberley (2000) provide the following six key characteristics of critical realism that form the basis for paradigmatic thought underlying this research;

1. Critical realism emphasizes a metaphysical ontology meaning that social and natural reality consists of intransitive objects that exist independently of human thought and mind.

2. The objects/entities mentioned in (1) may not be observable and different individuals may formulate different understanding of transitive realities based on their own paradigmatic and metaphorical standards.

3. By presenting the concept of epistemic relativism, critical realism rejects the idea of theory of truth

4. Critical realism takes science to mean something more than science rather than conventionally derived empirical and observable generalizations about the world.

5. The concept of science put forward by positivists has little role in thoroughly explaining actual scientific practice except for helping scientists explain their point of view about the world and how they used their concepts to try and explain the world to us.

6. Critical realism puts forward an epistemological defence of causal explanation by suggesting that we can understand cause and effect better by exploring the underlying mechanisms, otherwise unobservable, using 'retroduction.'

Box 1.1: 'Six key elements of critical realist thought as influenced by Roy Bhaskar', adapted from Johnson and Duberley (2000, pp. 154)

\section{Acknowledging Limitations of a Critical Realist}

While appreciating critical realism as an alternative to traditional paradigms it is important to remember that like other paradigms it also faces some criticisms and questions which are not easy to address. Since we have focused on highlighting the limitations of the dominant quantitative and qualitative paradigms during the earlier part of this paper, it would be downright unfair if one fails to appreciate the limitations of one's own preferred paradigmatic influence. A key issue that is potentially difficult to 
resolve for critical realism is the difficulty in knowing whether the instransitive structures that we as researchers have constructed based on our understanding are merely our imagination or real and non-empirical depiction of the actual truth. The metaphysical ontology suggested in Box 1.1, would be difficult to comprehend using our epistemological basis about what the world means to us. Also, by rejecting the possibility of theory-neutral observation it would become a question mark as to how we can establish the truth of our epistemically transitive constructions of reality. Not only that, if our experience of the world does not provide us with complete knowledge of the instransitive reality how can we then use our epistemological thoughts to develop an understanding of the instransitive ontological truth (Johnson \& Duberley, 2000).

There have been attempts to resolve some of these underlying criticisms that critical realism faces by bringing in influences from pragmatic school of thought i.e. pragmatism. An important point made by Rorty (1998) is that in order for knowledge to be considered useful and valid, it has to be supported by the pragmatic consensus of people who use a mutually comprehensible language for communicating with each other. Since this mutually comprehensible language can change from one community of people to another Rorty goes on to suggest that truth and reality are changeable according to variations in languages between communities. In an attempt to elaborate this further we take the viewpoint of Sayer (1992, pp. 83) who differentiates between 'thought objects' and 'real objects' by pointing out that there indeed is as external reality that is independent of human mind but it also is resistant to it and thus will remain unknowable. Emphasizing the need to understand the world in terms of our conceptual resources, he however points out that these resources 'do not determine the structure of the world itself'. Moreover, 'observation is neither theory-neutral nor theory-determined but theory-laden. Truth is neither absolute nor purely conventional and relative'. Bhaskar (1989b) himself implies a more realistic or pragmatic solution by suggesting that in social sciences theory and reality are causally dependent on each other. It means that although social theory is influenced by society and has consequences for it, this cannot be implied to suggest that a social theorist can 'construct' social reality'. Sayer (2004) has further underscored the need for critical realists not to engage themselves too much in striving to find out the absolute truth. Rather the focus should be on getting as close as possible to the intransitive metaphysical reality as possible.

\section{Conclusion}

This paper makes the case for researchers in Pakistan to consider use of critical realism as the paradigm underpinning social sciences research. In doing so issues of ontology and epistemology and ensuing paradigm wars have been discussed to highlight the difficulties a researcher faces in agreeing with a particular philosophical view of the world. Contrary to positivism and phenomenology, critical realism brings to our attention the difference between the natural and social worlds. Thus while 'epistemic relativism' the view that knowledge is socially constructed, is acceptable, 'judgemental relativism' the view that all depictions of the world are equally correct and without any particular preference for one over the other should be rejected. Bypassing the debate over deduction versus induction, the paper advocates the need for using 'retroduction' espoused by critical realism. Rather than generalizing results to a population or generating theory and in-depth insights, there is a need for researchers to focus on understanding the underlying causal mechanisms that can help provide a more truer picture of reality rather than the absolute truth about it 踐 


\section{References}

Atkinson, P.,\&Hammersley, M. (1994).Ethnography and participant observation.In N.K.Denzin, \& Y.S. Lincoln (Eds.),Handbook of qualitative research.Thousand Oaks, CA: Sage.

Ayer, A.J. (1959),Logical positivism. New York: The Free Press.

Bednarz, D. (1985). Quantity and quality in evaluation research: A divergent view. Evaluation and Program Planning, 8, 289-306.

Bhaskar, R. (1989a). The possibility of naturalism. Brighton: Harvester.

Bhaskar, R. (1989b). Reclaiming reality: A critical introduction to contemporary philosophy. London: Verso.

Bhaskar, R. (1997). A realist theory of science.New York: Verso.

Bhaskar, R. (1998). The possibility of naturalism: A philosophical critique of the contemporary human sciences. London: Routledge.

Biesta, G.,\&Burbules, N. (2003).Pragmatism and educational research.Lanham, MD: Rowman\& Littlefield.

Burrell, G. \& Morgan, G. (1979).Sociological paradigms and organizational analysis: Elements of the sociology of corporate life.London: Heinemann.

Campbell, D., Stanley, J.,\& Gage, N. (1963).Experimental and quasi-experimental designs for research. Chicago: Rand McNally

Collier, A. (1994). Critical realism: An introduction to Roy Bhaskar's philosophy. London: Verso.

Collis, J., Hussey, R., \&Myilibrary, R. (2003).Business research: A practical guide for undergraduate and postgraduate students. Basingstoke: Palgrave Macmillan.

Denzin, N., \&Lincoln, Y. (1994). Introduction: Entering the field of qualitative research. In N.K.Denzin\& Y.S. Lincoln (Eds.), Handbook of qualitative research. Thousand Oaks, CA: Sage.

Dobson, P. (2002). Critical realism and information systems research: Why bother with philosophy. Information Research, 7.

Easterby-Smith, M., Thorpe, R.,\& Lowe, A. (2002).Management research: An introduction. London: Sage.

Fairclough, N. (2005). Discourse analysis in organization studies: The case for critical realism. Organization Studies, 26, 915-939. 
Glaser, B., \&Strauss, A. (1977).The discovery of grounded theory: Strategies for qualitative research. Chicago: Aldine.

Guba, E.,\& Lincoln, Y. (1989).Fourth generation evaluation. Newbury Park, CA: Sage.

Guba, E., \& Lincoln, Y. (1994).Competing paradigms in qualitative research.In N.K.Denzin\& Y.S. Lincoln (Eds.), Handbook of Qualitative Research.Thousand Oaks, CA: Sage.

Guba, E.,\& Lincoln, Y. (2005).Paradigmatic controversies, contradictions, and emerging confluences. In C. Booth \&J. Harrington (Eds.), Developing Business Knowledge. Thousand Oaks, CA: Sage Publications.

Guba, E.G. (1990).The alternative paradigm dialog. In E.G.Guba (Ed.), The Paradigm Dialog. Newbury Park: Sage.

Haack, S. (1987).Realism.Synthese, 17, 275-299.

Hammersley, M. (1992).What's wrong with ethnography? Methodological explorations. London: Routledge.

Howe, K. (1988). Against the quantitative-qualitative incompatibility thesis or dogmas die hard. Educational Researcher, 17, 10-16.

Howe, K. (1992). Getting over the quantitative-qualitative debate.American Journal of Education, 100, 236-256.

Hussey, J., \&Hussey, R. (1997).Business research: A practical guide for undergraduate and postgraduate students. Basingstoke: Macmillan Business.

Johnson, P., \&Duberley, J. (2000).Understanding management research: An introduction to epistemology.London: Sage.

Johnson, R., \&Onwuegbuzie, A. (2004). Mixed methods research: A research paradigm whose time has come. Educational Researcher, 33, 14-26.

Kuhn, T. (1970).The structure of scientific revolutions. Chicago: Chicago University Press.

Lincoln, Y., \&Guba, E. (1985).Naturalistic inquiry. Newbury Park, CA: Sage.

Meehl, P.E. (1978). Theoretical risks and tabular asterisks: Sir Karl, Sir Ronald, and the slow progress of soft psychology. Journal of Consulting and Clinical Psychology, 46, 806-834.

Morse, J.M. (1991). Approaches to qualitative-quantitative methodological triangulation.Nursing Research, 40, 120-123.

Nagel, T. (1986).The View from Nowhere. New York: Oxford University Press. 
Newman, I., Ridnour, C.S., Newman, C.,\& De-Marco, G.M.P. (2003). A typology of research purposes and its relationship to mixed methods. In A. Tashakkori\&C. Teddlie (Eds.), Handbook of mixed methods in social and behavioral research.Thousand Oaks, CA: Sage.

Onwuegbuzie, A. J. (2000). Positivists, post-positivists, post-structuralists, and postmodernists: Why can't we all get along? Towards a framework for unifying research paradigms.Annual meeting of the association for the advancement of educational research. Ponte Vedra, FL.

Onwuegbuzie, A. J., \&Teddlie, C. (2003).A framework for analyzing data in mixed methods research.In A. Tashakkori\&C. Teddlie (Eds.), Handbook of Mixed Methods in Social and Behavioral Research. Thousand Oaks, CA: Sage.

Popper, K. (2002). The logic of scientific discovery New York: Routledge.

Reichardt, C.S.,\& Rallis, S.F. (1994). Qualitative and quantitative inquiries are not incompatible: A call for a new partnership. In C.S. Reichardt, \&S. F. Rallis, (Eds.), TheQualitative-Quantitative Debate: New Perspectives. San Francisco: Jossey-Bass.

Rorty, R. (1998). Truth and progress: Philosophical papers. Cambridge: Cambridge University Press.

Saunders, M., Lewis, P., \&Thornhill, A. (2006).Research methods for business students. Harlow: Financial Times Prentice Hall.

Sayer, A. (1992).Method in social science: A realist approach. London: Routledge.

Sayer, A. (2004). Why critical realism. In S. Fleetwood\&S. Ackroyd, (Eds.), Critical Realist Applications in Organisation and Management Studies. London: Routledge.

Schwandt, T. (2000). Three epistemological stances for qualitative inquiry: Interpretivism, hermeneutics, and social constructionism. In N. Denzin\&Y. Lincoln (Eds.), Handbook of Qualitative Research. Thousand Oaks, CA: Sage.

Sechrest, L., \&Sidani, S. (1995). Quantitative and qualitative methods: Is there an alternative? Evaluation and Program Planning, 18, 77-87.

Strauss, A.L., \& Corbin, J. (1998).Basics of qualitative research: Grounded theory procedures and techniques. Newbury Park, CA: Sage.

Tashakkori, A.,\&Teddlie, C. (2003).Handbook of Mixed Methods in Social and Behavioral Research. Thousand Oaks CA: Sage 